\author{
Anna Kobiałka \\ University of Life Sciences in Lublin \\ e-mail: anna.kobialka@up.lublin.pl \\ ORCID: 0000-0001-7788-7736
}

\title{
LOCAL GOVERNMENT EXPENDITURE IN THE LUBLIN VOIVODESHIP IN 2010-2018
}

DOI: $10.15611 / \mathrm{pn} .2020 .6 .08$
JEL Classification: $\mathrm{H} 72, \mathrm{H} 76$

(C) 2020 Anna Kobiałka

This is an open access article distributed under the Creative Commons Attribution-NonCommercial-NoDerivs license (http://creativecommons.org/licenses/by-nc-nd/3.0/)

Quote as: Kobiałka, A. (2020). Local government expenditure in the Lublin voivodeship in 2010-2018. Prace Naukowe Uniwersytetu Ekonomicznego we Wroctawiu, 64(6).

\begin{abstract}
Gmina' (i.e. a commune, a principal unit of administrative division in Poland) is required to perform specific tasks and incur expenditure related to its performance. Therefore, local government authorities must make decisions about the level and purpose of local expenditure. A particularly significant determinant of local development policy is expenditure on financing infrastructure investment. This paper aims to analyse and evaluate the expenditure level of 'gminas' located in Lublin voivodeship in 2010-2018. The analysis is based on a review of the dynamics of expenditure, its structure and level as well as changes in expenditure per capita. An area of special interest is the property investment expenditure of local government units. Communes in the Lublin voivodeship, similarly to those in the rest of Poland, have an increased amount of funds allocated to the performance of their tasks. A continuing increase in property expenditure can be observed, especially in the rural communes in the Lublin voivodeship, which is closely linked to the use of EU structural funds.
\end{abstract}

Keywords: 'gmina' (a commune), expenditure, property investment expenditure.

\section{Introduction}

Local government expenditure is the allocation of public funds by communes ('gmina') related to the performance of their tasks for the purposes of satisfying the needs of local communities regarding public utility services. The level of such expenditure is determined by the legal provisions in force and autonomy in their current spending policy (Galiński, 2016, p. 90). To this extent 'gminas' are more independent than to the amount of the revenue that is subject to stricter statutory 
restrictions, therefore they have considerably wider options of using expenditure-based instruments than revenue-based instruments (Perska, 2014, p. 287).

Expenditure refers to the allocation of funds from the budget of a local government unit to the performance of tasks of local significance (Ustawa $z$ dnia 8 marca 1990). Communes, on their own behalf and account, fulfill tasks related to technical infrastructure, social infrastructure, public safety and security as well as spatial and environmental order (Walczak and Kowalczyk, 2010, p. 18). Current expenditure is linked to the current operations of a local government unit, whilst property expenditure mostly refers to other funds allocated to investments (Milewska and Jóźwik, 2014, p. 127). Implementing their own local spending policy and determining the options available to them with regard to investment projects, is of essential importance for the development of local government units and for increasing their competitiveness (Kokot-Stępień, 2017, p. 144). Therefore, a particularly significant determinant of local development policy is expenditure on financing infrastructure investments. Such expenditure enables local government to create conditions fostering local development and supporting entrepreneurship, since such measures are the principal determinant of the socio-economic development of the specific area. Thus, financial management has an influence on the development of many areas of activity of a 'gmina' and governs the scope of local economic development, and the independence of the 'gmina' is determined by its financial resources and assets used in performing the assigned tasks (Zawora, 2010, p. 138). The independent financial policy of local government is mainly determined by the level of own revenues of a 'gmina', which sets out the scope of own tasks to be performed (Łukomska-Szarek, 2016, p. 770). Communes mostly use EU funds in financing their investments but this is connected with the necessity to ensure an adequate level of their own contribution (Dworakowska, 2018, p. 52). This paper aims to analyse and evaluate the level of expenditure of communes located in the Lublin voivodeship in the period 2010-2018.

\section{Methods}

The study aimed at analysing the expenditure of the principal units of local government in the Lublin voivodeship. The analysis was based on a review of the structure of expenditure, its dynamics and level as well as changes in expenditure per capita. An area of special interest was the expenditure on investment in property of local government units. The outcomes of the analysis include:

- the dynamics of expenditure according to basic categories taking local government unit types into account,

- the structure of expenditure, including the share of investment property expenditure in total expenditure, 
- the amount of expenditure per capita,

- the amount of property expenditure per capita,

- the amount of expenditure on education per capita,

- the dynamics of expenditure per capita,

- the structure of expenditure per capita,

- the expenditure per capita in respective types of ' gmina' in the Lublin voivodeship compared to such expenditure in the respective types of communes in the rest of Poland.

The review of the dynamics and structure of expenditure of local government units allowed a comparison between the average data for communes in Poland and those in the Lublin voivodeship, according to the respective types of 'gmina'. The study covered gminas excluding cities with poviat rights (county cities).The source of information used in the analysis was the Local Data Bank of Statistics of Poland (Bank Danych Lokalnych GUS [BDL], 2020).

\section{Results}

Local government expenditure in the analysed period increased at a similar rate both in Poland and in the Lublin voivodeship in increments of more than $10 \%$ a year (Table 1). Only in 2011-2013 was a small reduction in the level of expenditure noted in comparison to the previous year.

Larger disparities in the dynamics of local government expenditure can be observed for property expenditure only. On average, property expenditure in Polish communities decreased up to 2013, and then in 2015 and 2016. In the past two years a very dynamic year-on-year growth in expenditure has been recorded. In respective types of communes the increase in expenditure was nearly twofold in 2018. For current expenditure it was more even, from 5 to $10 \%$ a year; only in 2016 did the increase exceed $20 \%$. From that year on, communes commenced the disbursement of benefits to natural persons. The dynamics of growth in the current expenditure of communes located in the Lublin voivodeship was lower than the national average by less than one percentage point. In recent years, current expenditure in urban-rural communes of the analysed voivodeship has been characterised by the largest dynamics.

Although the current expenditure accounts for about $80 \%$ of total expenditure, property expenditure is extremely significant to local government units (Table 2). In the analysed period the share of current expenditure increased from, on average, less than $75 \%$ to nearly $90 \%$ in 2016 . During that time communes disbursed child benefits in line with the act on state aid in raising children (Ustawa, 2016). In the past two years a decreased share of current expenditure in total expenditure has been observed. 
Table 1. Dynamics of the value of expenditure of communes in Poland and in the Lublin voivodeship in 2010-2018 (in \%)

\begin{tabular}{|c|c|c|c|c|c|c|c|c|c|c|}
\hline \multicolumn{2}{|c|}{ 'Gmina' } & 2010 & 2011 & 2012 & 2013 & 2014 & 2015 & 2016 & 2017 & 2018 \\
\hline \multicolumn{11}{|c|}{ Total expenditure } \\
\hline \multirow[t]{4}{*}{ Poland } & Total & 113.9 & 99.9 & 98.5 & 101.2 & 107.1 & 101.0 & 114.2 & 114.1 & 113.5 \\
\hline & Urban & 109.2 & 100.4 & 98.9 & 98.8 & 107.8 & 101.3 & 113.7 & 112.8 & 113.0 \\
\hline & $\begin{array}{l}\text { Urban- } \\
\text {-rural }\end{array}$ & 113.4 & 100.8 & 99.2 & 101.2 & 107.0 & 101.6 & 115.0 & 114.6 & 113.5 \\
\hline & Rural & 116.9 & 99.1 & 97.8 & 102.4 & 106.8 & 100.4 & 113.9 & 114.3 & 113.8 \\
\hline \multirow{4}{*}{$\begin{array}{l}\text { Lublin } \\
\text { voivodeship }\end{array}$} & Total & 123.8 & 99.6 & 96.4 & 99.5 & 108.1 & 101.0 & 111.1 & 112.6 & 115.9 \\
\hline & Urban & 113.1 & 108.4 & 95.5 & 99.0 & 105.7 & 108.0 & 104.5 & 107.4 & 113.8 \\
\hline & $\begin{array}{l}\text { Urban- } \\
\text {-rural }\end{array}$ & 129.7 & 92.5 & 101.3 & 98.7 & 111.1 & 99.5 & 121.3 & 118.0 & 114.0 \\
\hline & Rural & 126.0 & 98.6 & 95.7 & 99.9 & 108.3 & 99.1 & 111.0 & 113.0 & 117.0 \\
\hline \multicolumn{11}{|c|}{ Property expenditure } \\
\hline \multirow[t]{4}{*}{ Poland } & Total & 123.6 & 91.3 & 77.7 & 92.9 & 117.3 & 93.8 & 75.6 & 149.7 & 160.1 \\
\hline & Urban & 110.3 & 91.0 & 79.1 & 84.3 & 119.4 & 93.5 & 81.9 & 144.6 & 158.9 \\
\hline & $\begin{array}{l}\text { Urban- } \\
\text {-rural }\end{array}$ & 121.2 & 93.6 & 79.4 & 90.6 & 117.3 & 94.6 & 77.3 & 148.1 & 158.3 \\
\hline & Rural & 132.6 & 89.9 & 75.9 & 98.7 & 116.5 & 93.2 & 71.8 & 153.3 & 161.8 \\
\hline \multirow{4}{*}{$\begin{array}{l}\text { Lublin } \\
\text { voivodeship }\end{array}$} & Total & 163.1 & 93.4 & 73.5 & 85.1 & 125.5 & 103.2 & 57.7 & 150.2 & 187.7 \\
\hline & Urban & 121.4 & 119.5 & 75.3 & 72.6 & 111.8 & 137.3 & 48.4 & 103.0 & 197.6 \\
\hline & $\begin{array}{l}\text { Urban- } \\
\text {-rural }\end{array}$ & 184.6 & 70.2 & 95.2 & 84.6 & 127.1 & 91.6 & 65.6 & 182.1 & 150.7 \\
\hline & Rural & 175.4 & 91.6 & 68.8 & 90.4 & 129.7 & 96.3 & 59.7 & 157.8 & 196.1 \\
\hline \multicolumn{11}{|c|}{ Current expenditure } \\
\hline \multirow[t]{4}{*}{ Poland } & Total & 111.0 & 102.8 & 104.7 & 103.1 & 105.0 & 102.6 & 122.1 & 109.6 & 105.5 \\
\hline & Urban & 108.9 & 103.3 & 104.3 & 101.8 & 105.8 & 102.8 & 119.3 & 109.0 & 105.7 \\
\hline & $\begin{array}{l}\text { Urban- } \\
\text {-rural }\end{array}$ & 111.0 & 103.1 & 105.0 & 103.6 & 105.0 & 103.2 & 122.4 & 110.4 & 106.0 \\
\hline & Rural & 112.2 & 102.4 & 104.7 & 103.3 & 104.7 & 102.2 & 123.3 & 109.3 & 105.1 \\
\hline \multirow{4}{*}{$\begin{array}{l}\text { Lublin } \\
\text { voivodeship }\end{array}$} & Total & 113.9 & 101.9 & 104.0 & 102.9 & 104.8 & 100.5 & 123.7 & 108.5 & 104.9 \\
\hline & Urban & 110.5 & 104.7 & 103.4 & 106.5 & 104.5 & 101.9 & 120.2 & 107.9 & 104.8 \\
\hline & $\begin{array}{l}\text { Urban- } \\
\text {-rural }\end{array}$ & 116.1 & 101.3 & 103.0 & 102.2 & 107.7 & 101.5 & 133.6 & 111.0 & 107.5 \\
\hline & Rural & 114.5 & 101.2 & 104.4 & 101.9 & 104.2 & 99.8 & 122.6 & 108.0 & 104.3 \\
\hline
\end{tabular}

Names of types of municipalities and expenditure are quoted on the basis of the Local Data Bank.

Source: own work based on (BDL, 2020). 
Table 2. Structure of expenditure of communes in Poland and in the Lublin voivodeship in 2010-2018 (in \%)

\begin{tabular}{|c|c|c|c|c|c|c|c|c|c|c|}
\hline \multicolumn{2}{|c|}{ 'Gmina' } & 2010 & 2011 & 2012 & 2013 & 2014 & 2015 & 2016 & 2017 & 2018 \\
\hline \multicolumn{11}{|c|}{ Property expenditure } \\
\hline \multirow[t]{4}{*}{ Poland } & Total & 25.07 & 22.91 & 18.07 & 16.58 & 18.17 & 16.86 & 11.16 & 14.64 & 20.64 \\
\hline & Urban & 23.52 & 21.32 & 17.04 & 14.54 & 16.10 & 14.87 & 10.71 & 13.73 & 19.31 \\
\hline & $\begin{array}{l}\text { Urban- } \\
\text {-rural }\end{array}$ & 24.30 & 22.57 & 18.07 & 16.17 & 17.73 & 16.51 & 11.10 & 14.36 & 20.02 \\
\hline & Rural & 26.43 & 23.98 & 18.61 & 17.92 & 19.55 & 18.14 & 11.43 & 15.32 & 21.79 \\
\hline \multirow{4}{*}{$\begin{array}{l}\text { Lublin } \\
\text { voivodeship }\end{array}$} & Total & 26.46 & 24.81 & 18.91 & 16.17 & 18.78 & 19.19 & 9.97 & 13.29 & 21.52 \\
\hline & Urban & 25.49 & 28.09 & 22.14 & 16.25 & 17.19 & 21.86 & 10.12 & 9.71 & 16.85 \\
\hline & $\begin{array}{l}\text { Urban- } \\
\text {-rural }\end{array}$ & 28.17 & 21.37 & 20.08 & 17.21 & 19.70 & 18.12 & 9.81 & 15.14 & 20.01 \\
\hline & Rural & 26.36 & 24.47 & 17.59 & 15.91 & 19.06 & 18.51 & 9.96 & 13.91 & 23.30 \\
\hline \multicolumn{11}{|c|}{ Current expenditure } \\
\hline \multirow[t]{4}{*}{ Poland } & Total & 74.93 & 77.09 & 81.93 & 83.42 & 81.83 & 83.14 & 88.84 & 85.36 & 79.36 \\
\hline & Urban & 76.48 & 78.68 & 82.96 & 85.46 & 83.90 & 85.13 & 89.29 & 86.27 & 80.69 \\
\hline & $\begin{array}{l}\text { Urban- } \\
\text {-rural }\end{array}$ & 75.70 & 77.43 & 81.93 & 83.83 & 82.27 & 83.49 & 88.90 & 85.64 & 79.98 \\
\hline & Rural & 73.57 & 76.02 & 81.39 & 82.08 & 80.45 & 81.86 & 88.57 & 84.68 & 78.21 \\
\hline \multirow{4}{*}{$\begin{array}{l}\text { Lublin } \\
\text { voivodeship }\end{array}$} & Total & 73.54 & 75.19 & 81.09 & 83.83 & 81.22 & 80.81 & 90.03 & 86.71 & 78.48 \\
\hline & Urban & 74.51 & 71.91 & 77.86 & 83.75 & 82.81 & 78.14 & 89.88 & 90.29 & 83.15 \\
\hline & $\begin{array}{l}\text { Urban- } \\
\text {-rural }\end{array}$ & 71.83 & 78.63 & 79.92 & 82.79 & 80.30 & 81.88 & 90.19 & 84.86 & 79.99 \\
\hline & Rural & 73.64 & 75.53 & 82.41 & 84.09 & 80.94 & 81.49 & 90.04 & 86.09 & 76.70 \\
\hline
\end{tabular}

Names of types of municipalities and expenditure are quoted on the basis of the Local Data Bank.

Source: own work based on (BDL, 2020).

The share of respective types of expenditures in total expenditure is correlated with the type of 'gmina'. Data referring both to communes in Poland and those in the Lublin voivodeship showed an identical relationship. The share of current expenditure in total expenditure was higher in cities than in urban-rural and rural communes. In those located in the Lublin voivodeship, current expenditure had a slightly higher share than average in Poland for each type of 'gmina'.

The share of property expenditure in the structure of local government expenditure systematically decreased until 2016, when it accounted for only $11 \%$ of local government expenditure. Such a limitation of property expenditure was connected with the end of the period of spending the EU funds obtained during 2007-2013. The funds were available for use until the end of 2015. In the past two years property expenditure has grew in importance, especially in 2018. An observable continuing trend was that rural communes both in Poland and in the Lublin voivodeship allocated 
proportionally more funds to property expenditure than communes of other types. An especially clear disparity can be seen between urban (municipalities) and rural communes.

The share of investment property expenditure in total expenditure is clearly linked to the cycles of financing under European Union aid programmes. The period 2010-2011 was when the EU funds were most intensively used, so the share of investment property expenditure of communities in total expenditure was also the highest throughout the analysed period (Table 3). Next to the communes of the Świętokrzyskie and Mazowieckie voivodeships, the communes of the Lubelskie voivodeship were among the most effective in terms of implementing infrastructural investments (cf. Kobiałka and Kubik, 2017). Since 2017 a growing trend has been observed again for the share of investment property expenditure in total expenditure. Communes located in the Lublin voivodeship allocated more expenditure to investment than those in the rest of Poland did on average. The respective types of communes show a trend where rural ones spend relatively more on investment than urban and urban-rural communes. This relationship can also be seen in the averaged values for the respective types of ' gmina' both in Poland and in the Lublin voivodeship which continued their investment projects using the EU funds granted for 2014-2020. The Lublin voivodeship was one of the largest beneficiaries of funds under

Table 3. Share of investment property expenditure of communes in Poland and in the Lublin voivodeship in their total expenditure in 2010-2018 (in \%)

\begin{tabular}{|c|c|c|c|c|c|c|c|c|c|c|}
\hline \multicolumn{2}{|c|}{ 'Gmina' } & 2010 & 2011 & 2012 & 2013 & 2014 & 2015 & 2016 & 2017 & 2018 \\
\hline \multirow[t]{4}{*}{ Poland } & Total & 24.7 & 22.5 & 17.7 & 16.2 & 17.8 & 16.5 & 10.8 & 14.3 & 20,3 \\
\hline & Urban & 23.0 & 20.7 & 16.3 & 13.9 & 15.5 & 14.5 & 10.3 & 13.3 & 18,9 \\
\hline & $\begin{array}{l}\text { Urban- } \\
\text {-rural }\end{array}$ & 23.8 & 22.0 & 17.6 & 15.7 & 17.3 & 16.1 & 10.6 & 14.0 & 19,5 \\
\hline & Rural & 26.3 & 23.8 & 18.4 & 17.7 & 19.4 & 17.9 & 11.3 & 15.2 & 21,7 \\
\hline \multirow{4}{*}{$\begin{array}{l}\text { Lublin } \\
\text { voivodeship }\end{array}$} & Total & 26.3 & 24.7 & 18.8 & 15.9 & 18.6 & 19.0 & 9.9 & 13.2 & 21,4 \\
\hline & Urban & 25.0 & 27.6 & 21.9 & 15.5 & 16.9 & 21.6 & 9.9 & 9.4 & 16,3 \\
\hline & $\begin{array}{l}\text { Urban- } \\
\text {-rural }\end{array}$ & 28.2 & 21.3 & 20.0 & 17.1 & 19.6 & 18.0 & 9.7 & 15.0 & 19,9 \\
\hline & Rural & 26.3 & 24.5 & 17.6 & 15.8 & 19.0 & 18.4 & 9.9 & 13.8 & 23,3 \\
\hline \multicolumn{11}{|c|}{ Ratio of expenditure in Lublin voivodeship to expenditure in Poland (\%) } \\
\hline Total & & 106.5 & 109.8 & 106.2 & 98.1 & 104.5 & 115.2 & 91.7 & 92.3 & 105.4 \\
\hline Urban & & 108.7 & 133.3 & 134.4 & 111.5 & 109.0 & 149.0 & 96.1 & 70.7 & 86.2 \\
\hline Urban-rural & & 118.5 & 96.8 & 113.6 & 108.9 & 113.3 & 111.8 & 91.5 & 107.1 & 102.1 \\
\hline Rural & & 100.0 & 102.9 & 95.7 & 89.3 & 97.9 & 102.8 & 87.6 & 90.8 & 107.4 \\
\hline
\end{tabular}

Names of types of municipalities and expenditure are quoted on the basis of the Local Data Bank.

Source: own work based on (BDL, 2020). 
Table 4. Amount of expenditure per capita in communes in Poland and in the Lublin voivodeship in 2010-2018 (in PLN)

\begin{tabular}{|c|c|c|c|c|c|c|c|c|c|c|}
\hline \multicolumn{2}{|c|}{ 'Gmina' } & 2010 & 2011 & 2012 & 2013 & 2014 & 2015 & 2016 & 2017 & 2018 \\
\hline \multicolumn{11}{|c|}{ Total expenditure } \\
\hline \multirow[t]{4}{*}{ Poland } & Total & 3081 & 3075 & 3025 & 3076 & 3292 & 3329 & 3803 & 4338 & 4924 \\
\hline & Urban & 2892 & 2908 & 2883 & 2914 & 3153 & 3212 & 3671 & 4156 & 4710 \\
\hline & $\begin{array}{l}\text { Urban- } \\
\text {-rural }\end{array}$ & 3021 & 3030 & 3003 & 3042 & 3239 & 3285 & 3761 & 4290 & 4847 \\
\hline & Rural & 3237 & 3206 & 3124 & 3192 & 3412 & 3429 & 3910 & 4476 & 5103 \\
\hline \multirow{4}{*}{$\begin{array}{l}\text { Lublin } \\
\text { voivodeship }\end{array}$} & Total & 2998 & 2996 & 2897 & 2894 & 3137 & 3181 & 3545 & 4006 & 4662 \\
\hline & Urban & 2762 & 3008 & 2885 & 2877 & 3055 & 3318 & 3491 & 3773 & 4318 \\
\hline & $\begin{array}{l}\text { Urban- } \\
\text {-rural }\end{array}$ & 3001 & 2791 & 2842 & 2820 & 3054 & 3059 & 3423 & 3964 & 4434 \\
\hline & Rural & 3075 & 3040 & 2914 & 2917 & 3184 & 3164 & 3596 & 4095 & 4841 \\
\hline \multicolumn{11}{|c|}{ Property expenditure } \\
\hline \multirow[t]{4}{*}{ Poland } & Total & 772 & 704 & 547 & 510 & 598 & 561 & 424 & 635 & 1016 \\
\hline & Urban & 680 & 620 & 491 & 424 & 508 & 478 & 393 & 571 & 909 \\
\hline & $\begin{array}{l}\text { Urban- } \\
\text {-rural }\end{array}$ & 734 & 684 & 543 & 492 & 574 & 542 & 418 & 616 & 970 \\
\hline & Rural & 855 & 769 & 581 & 572 & 667 & 622 & 447 & 686 & 1112 \\
\hline \multirow{4}{*}{$\begin{array}{l}\text { Lublin } \\
\text { voivodeship }\end{array}$} & Total & 793 & 743 & 548 & 468 & 589 & 610 & 353 & 532 & 1003 \\
\hline & Urban & 704 & 845 & 639 & 468 & 525 & 725 & 353 & 366 & 728 \\
\hline & $\begin{array}{l}\text { Urban- } \\
\text {-rural }\end{array}$ & 845 & 597 & 571 & 485 & 602 & 554 & 336 & 600 & 887 \\
\hline & Rural & 810 & 744 & 513 & 464 & 607 & 586 & 358 & 570 & 1128 \\
\hline \multicolumn{11}{|c|}{ Expenditure for education } \\
\hline \multirow[t]{4}{*}{ Poland } & Total & 1025 & 1071 & 1123 & 1143 & 1179 & 1220 & 1251 & 1336 & 1449 \\
\hline & Urban & 901 & 950 & 996 & 1027 & 1065 & 1118 & 1164 & 1242 & 1352 \\
\hline & $\begin{array}{l}\text { Urban- } \\
\text {-rural }\end{array}$ & 1015 & 1054 & 1106 & 1125 & 1161 & 1204 & 1234 & 1327 & 1436 \\
\hline & Rural & 1103 & 1154 & 1208 & 1222 & 1256 & 1289 & 1312 & 1394 & 1512 \\
\hline \multirow{4}{*}{$\begin{array}{l}\text { Lublin } \\
\text { voivodeship }\end{array}$} & Total & 1014 & 1076 & 1126 & 1142 & 1166 & 1191 & 1209 & 1253 & 1384 \\
\hline & Urban & 952 & 997 & 1058 & 1114 & 1142 & 1192 & 1235 & 1286 & 1392 \\
\hline & $\begin{array}{l}\text { Urban- } \\
\text {-rural }\end{array}$ & 1017 & 1088 & 1140 & 1115 & 1150 & 1192 & 1208 & 1221 & 1333 \\
\hline & Rural & 1033 & 1099 & 1144 & 1158 & 1178 & 1191 & 1201 & 1250 & 1396 \\
\hline \multirow{2}{*}{\multicolumn{11}{|c|}{$\begin{array}{r}\text { Ratio of gminas expenditure in Lublin voivodeship to } g \\
\text { Total expenditure }\end{array}$}} \\
\hline 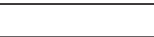 & & & & & & & & & & \\
\hline Total & & 97.30 & 97.43 & 95.77 & 94.11 & 95.29 & 95.54 & 93.21 & 92.35 & 94.68 \\
\hline Urban & & 95.52 & 103.4 & 100.1 & 98.73 & 96.88 & 103.3 & 95.10 & 90.78 & 91.68 \\
\hline Urban-rural & & 99.35 & 92.13 & 94.62 & 92.71 & 94.28 & 93.15 & 91.00 & 92.40 & 91.48 \\
\hline Rural & & 94.98 & 94.80 & 93.30 & 91.40 & 93.34 & 92.28 & 91.97 & 91.49 & 94.86 \\
\hline \multicolumn{11}{|c|}{ Property expenditure } \\
\hline \multicolumn{2}{|l|}{ Total } & 102.7 & 105.5 & 100.2 & 91.76 & 98.49 & 108.7 & 83.25 & 83.78 & 98.72 \\
\hline \multicolumn{2}{|l|}{ Urban } & 103.5 & 136.3 & 130.1 & 110.4 & 103.4 & 151.7 & 89.82 & 64.10 & 80.09 \\
\hline \multicolumn{2}{|l|}{ Urban-rural } & 115.1 & 87.28 & 105.2 & 98.58 & 104.9 & 102.2 & 80.38 & 97.40 & 91.44 \\
\hline \multicolumn{2}{|l|}{ Rural } & 94.74 & 96.75 & 88.30 & 81.12 & 91.00 & 94.21 & 80.09 & 83.09 & 101.4 \\
\hline \multicolumn{11}{|c|}{ Expenditure for education } \\
\hline \multicolumn{2}{|l|}{ Total } & 98.93 & 100.4 & 100.3 & 99.91 & 98.93 & 97.64 & 96.66 & 93.78 & 95.51 \\
\hline \multicolumn{2}{|l|}{ Urban } & 105.6 & 104.9 & 106.3 & 108.5 & 107.2 & 106.7 & 106.1 & 103.5 & 102.9 \\
\hline \multicolumn{2}{|l|}{ Urban-rural } & 100.19 & 103.22 & 103.1 & 99.1 & 99.1 & 99.1 & 97.9 & 92.0 & 92.8 \\
\hline \multicolumn{2}{|l|}{ Rural } & 93.72 & 95.21 & 94.77 & 94.7 & 93.8 & 92.4 & 91.5 & 89.7 & 92.3 \\
\hline
\end{tabular}

Names of types of municipalities and expenditure are quoted on the basis of the Local Data Bank.

Source: own work based on (BDL, 2020). 
regional programmes in Poland in the analyzed period (European Funds Portal, n.d.). Local government units of the Lublin voivodeship had one of the highest values of European funds per capita. ${ }^{1}$

Expenditure per capita is a significant complement to the analysis of budget expenditure of communes because it demonstrates the level of expenditure.

In the analysed period, local government expenditure per capita ranged from PLN 3000 in 2010 to nearly PLN 5000 in 2018 (Table 4). Investment property expenditure per capita was from PLN 800 to PLN 1000, while PLN 1000 to PLN 1400 per capita were spent on education. Communes in the Lublin voivodeship incurred less expenditure per capita than the communes of Poland did on average. In the analysed period there were only three cases when local government expenditure in the Lublin voivodeship was higher than the average expenditure. Only in cities in the Lublin voivodeship in 2011, 2012 and 2015 was it above average values for cities and towns in Poland. About half of the communes of the Lublin voivodeship recorded expenditure per capita higher than the national average (Urząd Statystyczny w Lublinie, 2017, 2019). At the beginning of the analysed period, property expenditure of communes located in the Lublin voivodeship per capita was higher than on average in the rest of Poland. A particularly large disparity was observed in cities and towns, which in 2015 allocated 50\% more than other cities of Poland. In turn, from 2016 the property expenditure of communes in the Lublin region was about $20 \%$ lower than the average in Poland. As regards expenditure on education, communes in the Lublin voivodeship also allocated even 6\% less than others in Poland. Only local municipalities recorded higher expenditure than others in Poland did on average throughout the period.

Expenditure per capita decreased until 2012 (Table 5). From 2013 its national average values slowly began increasing, while those in the Lublin voivodeship noted a further decrease in the level of expenditure or an unchanged value for rural ones. In the following year, local government expenditure in the Lublin voivodeship was about 1 percentage point higher than the average in Poland, and in rural communes this increase corresponded to 2 percentage points. In 2016, expenditure per capita also increased due to child benefit disbursements realised by communes under the " $500+$ Programme" by about $14 \%$. In communes in the Lublin voivodeship the increase was slightly lower, but larger disparities were noticeable between the respective types of those. In the past two years expenditure increased by more than $10 \%$ year on year. The differences between communes at the national and regional level illustrated a larger growth in expenditure per capita, especially in rural areas.

In the analysed period, property expenditure generally decreased up to 2016, except in 2013 when the expenditure of communes in Poland increased by approximately $10 \%$. In those located in the Lublin voivodeship property expenditure increased by $25 \%$, reaching the lowest level in municipalities (12\%), and the highest

\footnotetext{
${ }^{1}$ Own calculations based on (European Funds Portal, n.d.; Główny Urząd Statystyczny, n.d.).
} 
Table 5. Dynamics of expenditure per capita in communes in Poland and in the Lublin voivodeship in 2010-2018 (in \%)

\begin{tabular}{|c|c|c|c|c|c|c|c|c|c|}
\hline \multicolumn{2}{|c|}{ 'Gmina' } & 2011 & 2012 & 2013 & 2014 & 2015 & 2016 & 2017 & 2018 \\
\hline \multicolumn{10}{|c|}{ Total expenditure } \\
\hline \multirow[t]{4}{*}{ Poland } & Total & 99.81 & 98.38 & 101.66 & 107.04 & 101.12 & 114.25 & 114.06 & 113.50 \\
\hline & Urban & 100.57 & 99.14 & 101.08 & 108.20 & 101.88 & 114.27 & 113.22 & 113.32 \\
\hline & $\begin{array}{l}\text { Urban- } \\
\text {-rural }\end{array}$ & 100.30 & 99.13 & 101.27 & 106.50 & 101.39 & 114.52 & 114.05 & 112.98 \\
\hline & Rural & 99.05 & 97.41 & 102.20 & 106.87 & 100.51 & 114.02 & 114.50 & 114.00 \\
\hline \multirow{4}{*}{$\begin{array}{l}\text { Lublin } \\
\text { voivodeship }\end{array}$} & Total & 99.94 & 96.70 & 99.90 & 108.39 & 101.38 & 111.46 & 113.00 & 116.37 \\
\hline & Urban & 108.91 & 95.90 & 99.73 & 106.16 & 108.64 & 105.20 & 108.08 & 114.44 \\
\hline & $\begin{array}{l}\text { Urban- } \\
\text {-rural }\end{array}$ & 93.01 & 101.80 & 99.23 & 108.30 & 100.18 & 111.88 & 115.80 & 111.86 \\
\hline & Rural & 98.85 & 95.87 & 100.11 & 109.15 & 99.36 & 113.63 & 113.90 & 118.20 \\
\hline \multicolumn{10}{|c|}{ Property expenditure } \\
\hline \multirow[t]{4}{*}{ Poland } & Total & 91.19 & 77.70 & 93.24 & 117.25 & 93.81 & 75.58 & 149.76 & 160.00 \\
\hline & Urban & 91.18 & 79.19 & 86.35 & 119.81 & 94.09 & 82.22 & 145.29 & 159.19 \\
\hline & $\begin{array}{l}\text { Urban- } \\
\text {-rural }\end{array}$ & 93.19 & 79.39 & 90.61 & 116.67 & 94.43 & 77.12 & 147.37 & 157.47 \\
\hline & Rural & 89.94 & 75.55 & 98.45 & 116.61 & 93.25 & 71.86 & 153.47 & 162.10 \\
\hline \multirow{4}{*}{$\begin{array}{l}\text { Lublin } \\
\text { voivodeship }\end{array}$} & Total & 93.69 & 73.76 & 85.40 & 125.85 & 103.57 & 57.87 & 150.71 & 188.53 \\
\hline & Urban & 120.03 & 75.62 & 73.24 & 112.18 & 138.10 & 48.69 & 103.68 & 198.91 \\
\hline & $\begin{array}{l}\text { Urban- } \\
\text {-rural }\end{array}$ & 70.65 & 95.64 & 84.94 & 124.12 & 92.03 & 60.65 & 178.57 & 147.83 \\
\hline & Rural & 91.85 & 68.95 & 90.45 & 130.82 & 96.54 & 61.09 & 159.22 & 197.89 \\
\hline \multicolumn{10}{|c|}{ Expenditure for education } \\
\hline \multirow[t]{4}{*}{ Poland } & Total & 104.57 & 104.77 & 101.84 & 103.11 & 103.50 & 102.54 & 106.79 & 108.49 \\
\hline & Urban & 105.45 & 104.79 & 103.15 & 103.70 & 105.00 & 104.08 & 106.73 & 108.87 \\
\hline & $\begin{array}{l}\text { Urban- } \\
\text {-rural }\end{array}$ & 103.85 & 104.91 & 101.71 & 103.16 & 103.72 & 102.52 & 107.50 & 108.28 \\
\hline & Rural & 104.69 & 104.62 & 101.18 & 102.79 & 102.62 & 101.80 & 106.26 & 108.47 \\
\hline \multirow{4}{*}{$\begin{array}{l}\text { Lublin } \\
\text { voivodeship }\end{array}$} & Total & 106.13 & 104.62 & 101.48 & 102.10 & 102.15 & 101.50 & 103.61 & 110.50 \\
\hline & Urban & 104.72 & 106.14 & 105.33 & 102.46 & 104.45 & 103.58 & 104.12 & 108.26 \\
\hline & $\begin{array}{l}\text { Urban- } \\
\text {-rural }\end{array}$ & 107.00 & 104.74 & 97.81 & 103.16 & 103.66 & 101.31 & 101.08 & 109.17 \\
\hline & Rural & 106.36 & 104.13 & 101.14 & 101.77 & 101.06 & 100.85 & 104.12 & 111.64 \\
\hline
\end{tabular}

Names of types of municipalities and expenditure are quoted on the basis of the Local Data Bank.

Source: own work based on (BDL, 2020).

in rural communes $(30 \%)$. The past two years showed a very dynamic growth in property expenditure, which was particularly visible in communes located in the Lublin voivodeship. Rural communes recorded an almost twofold increase. The most significant current expenditure is expenditure on education and its increase in the analysed period was the most stable - at the level of $4 \%$ to $8 \%$ per cent a year. 
Table 6. Structure of expenditure per capita in communes in Poland and in the Lublin voivodeship in 2010-2018 (in \%)

\begin{tabular}{|c|c|c|c|c|c|c|c|c|c|c|}
\hline \multicolumn{2}{|c|}{ 'Gmina' } & 2010 & 2011 & 2012 & 2013 & 2014 & 2015 & 2016 & 2017 & 2018 \\
\hline \multicolumn{11}{|c|}{ Property expenditure } \\
\hline \multirow[t]{4}{*}{ Poland } & Total & 25.06 & 22.89 & 18.08 & 16.58 & 18.16 & 16.85 & 11.15 & 14.64 & 20.64 \\
\hline & Urban & 23.52 & 21.32 & 17.03 & 14.55 & 16.11 & 14.88 & 10.71 & 13.74 & 19.30 \\
\hline & $\begin{array}{l}\text { Urban- } \\
\text {-rural }\end{array}$ & 24.30 & 22.58 & 18.08 & 16.18 & 17.72 & 16.50 & 11.11 & 14.36 & 20.01 \\
\hline & Rural & 26.41 & 23.98 & 18.60 & 17.92 & 19.55 & 18.14 & 11.43 & 15.32 & 21.79 \\
\hline \multirow{4}{*}{$\begin{array}{l}\text { Lublin } \\
\text { voivodeship }\end{array}$} & Total & 26.45 & 24.80 & 18.91 & 16.17 & 18.77 & 19.18 & 9.96 & 13.28 & 21.52 \\
\hline & Urban & 25.49 & 28.09 & 22.15 & 16.27 & 17.19 & 21.85 & 10.11 & 9.70 & 16.86 \\
\hline & $\begin{array}{l}\text { Urban- } \\
\text {-rural }\end{array}$ & 28.16 & 21.39 & 20.09 & 17.20 & 19.71 & 18.11 & 9.82 & 15.14 & 20.01 \\
\hline & Rural & 26.34 & 24.48 & 17.60 & 15.90 & 19.06 & 18.52 & 9.96 & 13.92 & 23.30 \\
\hline \multicolumn{11}{|c|}{ Expenditure for education } \\
\hline \multirow[t]{4}{*}{ Poland } & Total & 33.26 & 34.84 & 37.10 & 37.17 & 35.80 & 36.65 & 32.89 & 30.79 & 29.43 \\
\hline & Urban & 31.16 & 32.67 & 34.53 & 35.24 & 33.78 & 34.81 & 31.70 & 29.89 & 28.71 \\
\hline & $\begin{array}{l}\text { Urban- } \\
\text {-rural }\end{array}$ & 33.61 & 34.80 & 36.83 & 36.99 & 35.83 & 36.65 & 32.81 & 30.92 & 29.64 \\
\hline & Rural & 34.06 & 36.00 & 38.66 & 38.28 & 36.82 & 37.59 & 33.56 & 31.15 & 29.64 \\
\hline \multirow{4}{*}{$\begin{array}{l}\text { Lublin } \\
\text { voivodeship }\end{array}$} & Total & 33.81 & 35.91 & 38.85 & 39.46 & 37.17 & 37.45 & 34.11 & 31.27 & 29.69 \\
\hline & Urban & 34.46 & 33.13 & 36.67 & 38.73 & 37.38 & 35.93 & 35.38 & 34.09 & 32.25 \\
\hline & $\begin{array}{l}\text { Urban- } \\
\text {-rural }\end{array}$ & 33.89 & 38.99 & 40.11 & 39.54 & 37.66 & 38.97 & 35.29 & 30.80 & 30.06 \\
\hline & Rural & 33.61 & 36.16 & 39.27 & 39.68 & 36.99 & 37.62 & 33.39 & 30.53 & 28.83 \\
\hline
\end{tabular}

Names of types of municipalities and expenditure are quoted on the basis of the Local Data Bank.

Source: own work based on (BDL, 2020).

The amount of property expenditure per capita in 2010 accounted for about $25 \%$ of the total expenditure (Table 6). This ratio systematically decreased up to 2016 when property expenditure accounted for approximately $10 \%$ of the total expenditure per capita. The reduced share of property expenditure was a result of the increase in current expenditure. After 2016. the share of property expenditure per investment property increased by more than $10 \%$ and up to $20 \%$. In communes located in the Lublin voivodeship the share of property expenditure in total expenditure per capita was often higher than in the corresponding types of communities in Poland. This relationship is particularly clear in 2015 and 2018. A symptomatic decrease was observed in the share of property expenditure in 2016 in the urban-rural and rural communes located in the Lublin voivodeship in comparison to others of this type elsewhere in Poland.

Expenditure on education constitutes a very large burden on local government budgets. The above-mentioned expenditure accounted for $30 \%$ to nearly $40 \%$ of all 
local government expenditure per capita. The share of expenditure on education increased up to 2015. and in the following year. it started to decrease to around $30 \%$. In the budgets of communes located in the Lublin voivodeship. the share of expenditure on education in the total expenditure in 2016 was slightly higher than in other areas in Poland. Over the past two years a lower share compared to the national level was noted in rural communes. while in urban and in urban-rural communes it was higher.

\section{Conclusion}

The scope of tasks performed by communes has become increasingly wider. hence their higher expenditure. Over the past decade. local government units have continued to use EU funds intensively. allowing a wide range of investment in infrastructure. therefore. property expenditure has been continuously growing. Since 2016 the increase in current expenditure has been particularly visible in connection with the communes' obligation to disburse child benefits under the government scheme. It is symptomatic that rural communes intensively realise property expenditure. which is clearly illustrated by the example of those in the Lublin voivodeship. The structure of local government expenditure in the Lublin voivodeship is increasingly near to the average structure of local government expenditure in Poland. Communes in the Lublin voivodeship made efficient use of the options of financing and realising investments in infrastructure. In 2018 they showed a share of investment property expenditure in their total expenditure higher than others in Poland. whereas this increase was mainly recorded for urban-rural and rural communes. Expenditure per capita has also been growing intensively. Since 2018 the value and share of property expenditure in the structure of expenditure has been growing dynamically. especially in rural communes in the Lublin voivodeship.

\section{References}

Bank Danych Lokalnych GUS [BDL]. (2020). Retrieved from http://bdl.stat.gov.pl/BDL/dane

Dworakowska, M. (2018). Dochody budżetowe jednostek samorządu terytorialnego z perspektywy absorpcji funduszy unijnych. Optimum. Economic Studies, 93(3), 51-62.

European Funds Portal. (n.d.). Retrieved from https://www.funduszeeuropejskie.gov.pl/en/site/learnmore-about-european-funds/discover-how-the-funds-work/european-funds-in-poland/

Główny Urząd Statystyczny. (n.d.). Retrieved from https://stat.gov.pl/obszary-tematyczne/ludnosc/ludnosc/powierzchnia-i-ludnosc-w-przekroju-terytorialnym-w-2019-roku.7.16.html

Galiński, P. (2016). Struktura wydatków gmin w Polsce. Zarządzanie i Finanse. Journal of Management and Finance, 14(4), 89-100.

Kobiałka, A., and Kubik, R. (2017). Efficiency of the investment activity of Polish communes in rural areas. In A. Raupelienè (ed.), The 8th international scientific conference rural development 2017: Bioeconomy challenges: conference proceedings (pp. 1087-1091). DOI: 10.15544/RD.2017.207 
Kokot-Stępień, P. (2017). Finansowe uwarunkowania rozwoju jednostek samorządu terytorialnego na przykładzie gmin województwa śląskiego. Studia Ekonomiczne. Zeszyty Naukowe Uniwersytetu Ekonomicznego w Katowicach, (341), 144-158.

Łukomska-Szarek, J. (2016). Analiza pionowa i pozioma dochodów własnych oraz poziomu samofinansowania samorządów lokalnych w Polsce. cz. 1. Finanse. Rynki Finansowe. Ubezpieczenia, 82(4), 769-780.

Milewska, A., and Jóźwik, M. (2014). Organization and changes of local government finance system in view of the implementation of participatory budgeting. Acta Scientarum Polonorum Oeconomia, 13(4), 125-134.

Perska, A. (2014). Wydatki inwestycyjne jednostek samorządu terytorialnego jako instrument wspierania przedsiębiorczości. Przedsiębiorczość - Edukacja, (10), 285-294.

Urząd Statystyczny w Lublinie. (2017). Budżety jednostek samorządu terytorialnego w województwie lubelskim w 2016 r. Retrieved from Lublin.stat.gov.pl. budzety2016.pdf

Urząd Statystyczny w Lublinie. (2019), Budżety jednostek samorządu terytorialnego w województwie lubelskim w 2018 r. Retrieved from Lublin.stat.gov.pl. budzety2018_1.pdf

Ustawa z dnia 8 marca 1990 r. o samorządzie gminnym (Dz. U. z 2019 r. poz. 506 ze zm.)

Ustawa z dnia 11 lutego 2016 r. o pomocy państwa w wychowywaniu dzieci (Dz. U. 2016, poz.195. ze $\mathrm{zm}$.)

Walczak, M., and Kowalczyk, M. (2010). Rachunkowość i budżetowanie w zarządzaniu finansami gmi$n y$. Warszawa: Difin.

Zawora, J. (2010). Samodzielność finansowa samorządów gminnych Podkarpacia. Zeszyty Naukowe $S G G W,(81), 137-145$.

\section{WYDATKI GMIN WOJEWÓDZTWA LUBELSKIEGO W LATACH 2010-2018}

Streszczenie: Gminy zobowiązane są do realizacji określonych zadań i ponoszenia na te cele wydatków. Władze samorządowe w związku z tym muszą podejmować decyzje o poziomie wydatków gminnych i kierunkach ich wydatkowania. Szczególnie istotnym wyznacznikiem polityki rozwojowej gmin są wydatki finansujące realizację inwestycji infrastrukturalnych. Celem artykułu jest analiza i ocena poziomu wydatków gmin województwa lubelskiego w latach 2010-2018. Analiza opiera się na badaniu dynamiki wydatków, ich struktury oraz poziomu i zmian wydatków w przeliczeniu na 1 mieszkańca. Szczególnym obszarem zainteresowania są wydatki inwestycyjne jednostek samorządu terytorialnego. Gminy województwa lubelskiego, podobnie jak gminy w kraju, przeznaczają coraz więcej środków na realizację powierzonych im zadań. Szczególnie widoczny jest stały wzrost wydatków majątkowych, zwłaszcza w gminach wiejskich województwa lubelskiego, co jest ściśle powiązane $\mathrm{z}$ wykorzystaniem funduszy strukturalnych z UE.

Slowa kluczowe: gminy, wydatki, wydatki inwestycyjne. 